\title{
Presence of Antibiotic-Resistant in Staphylococcal Subclinical Mastitis in Several Regencies of East Java, Indonesia
}

\author{
D. C. Widianingrum ${ }^{\mathrm{a}}$, H. Khasanah ${ }^{\mathrm{a}}$, \& H. S. Addy ${ }^{\mathrm{b}, *}$ \\ aDepartment of Animal Science, Faculty of Agriculture, University of Jember \\ ${ }^{b}$ Division of Biology Molecule and Biotechnology, Center for Development of Advanced Sciences and Technology, \\ University of Jember \\ Jalan Kalimantan No 37, Jember 68121, Indonesia \\ *Corresponding author: hsaddy.faperta@unej.ac.id \\ (Received 09-03-2021; Revised 19-07-2021; Accepted 27-07-2021)
}

\begin{abstract}
Staphylococcal mastitis has been reported as a serious dairy disease in various regions around the world. The occurrence of resistant strains in Staphylococcus species to antibiotics has triggered alternative treatment substituting antibiotic usage on the global scene. This study aimed to investigate the presence of antibiotic-resistant genes in Staphylococcal subclinical-mastitis cases present in several regencies of East Java Province, Indonesia. A total of 592 quarter milk samples were collected from 62 farms in the region with high dairy cattle populations in Lumajang, Banyuwangi, Malang, Sidoarjo, Jember, Pasuruan, Probolinggo, and Mojokerto. Subclinical-mastitis samples were screened using the California mastitis test (CMT). Positive CMT samples were grown on the selective Staphylococcus media and tested for their biochemical properties. The polymerase chain reaction was performed to detect the presence of antibiotic-resistant genes in all isolates (Staphylococcus $s p$ ) using a specific pair-primer for $m e c A, b l a Z$, tet $K$, and tet $M$ genes. The result showed that about $67 \%$ of milk samples were subclinical mastitis in several regencies of East Java. About $\mathbf{1 7 . 1 2} \%$ of subclinical mastitis was caused by Staphylococcus species (Staphylococcus aureus, Staphylococcus epidermidis, and other non-aureus Staphylococci (NAS)). The most prevalent region of Staphylococcal subclinical-mastitis was recorded in Jember. However, only NAS species obtained from Mojokerto, Malang, Probolinggo, and Banyuwangi were detected to have a blaZ gene responsible for penicillin resistance. In conclusion, the appearance of the antibiotic-resistant gene in NAS species found in several regencies of East Java can be used as important information to evaluate Staphylococcal subclinical-mastitis treatment.
\end{abstract}

Keywords: Staphylococcal subclinical-mastitis; antibiotic-resistant genes; penicillin; dairy milk

\section{INTRODUCTION}

Mastitis is a potential zoonotic disease affecting the dairy industry and is divided into clinical and subclinical mastitis (Abebe et al., 2016). Clinical mastitis is defined as inflammation of the udder with swelling, redness, and fever symptoms, while subclinical mastitis is an asymptomatic inflammation (Oliviera et al., 2013; Koop et al., 2010). In addition, several infectious bacteria have been documented to be associated with clinical or subclinical mastitis, such as Staphylococcus aureus, non-aureus Staphylococci (NAS), Streptococcus agalactiae, Streptococcus dysgalactiae, Streptococcus uberis, Escherichia coli, Corynebacterium bovis, and Pseudomonas aeruginosa (Windria et al., 2016; Heikkilä et al., 2018; Cervinkova et al., 2013; Gonçalves et al., 2020; Yuan et al., 2017). According to its prevalence, subclinical mastitis becomes more challenging due to the diagnosis system, persistence, and impact on dairy production (Mbindyo et al., 2020).
Antibiotic is commonly used in several dairy farming to treat mastitis disease (Poizat et al., 2017). However, the use of antibiotics in livestock treatment adversely affects the benefits of further prevention and control of mastitis by increasing the antimicrobialresistant (AMR) strain (Chandrasekaran et al., 2014), contaminating livestock products (Vishnuraj et al., 2016), and resulting in the economic losses (Aslam et al., 2018). Several mastitis-associated bacteria such as S. aureus isolated from human foodborne-disease cases and animal milk are resistant to several antibiotics. Moreover, the most methicillin-resistant $S$. aureus (MRSA) is also found in humans (Widianingrum et al., 2016). Notably, some mastitis-associated bacteria carry antibiotic-resistant genes such as the mecA gene responsible for methicillinresistant, blaZ for penicillin, as well as tet $K$ and tet $M$ for tetracycline (Hoekstra et al., 2020). Consequently, the antimicrobial treatment is no longer effective in preventing and controlling mastitis in dairy farming (Chandrasekaran et al., 2014). 
Recently, the prevalence study of subclinical mastitis to evaluate regional treatment in East Java is limited to particular districts (Khairullah et al., 2019; Ramandinianto et al., 2020). Additionally, some reports have shown that antibiotic treatment in East Java is high and correlates with the incidence of antibiotic-resistant strains associated with mastitis (Khairullah et al., 2019). Meanwhile, clarification of the antibiotic-resistant genes in subclinical mastitis agents in East Java has not been widely reported. Therefore, this study aimed to investigate the presence of antibiotic-resistance genes in Staphylococcal subclinical-mastitis cases present in several regencies of East Java Province, Indonesia.

\section{MATERIALS AND METHODS}

The milk samples were obtained from lactating dairy cows, and each farmer carried out the milking according to their operational procedures. A laboratory study was conducted to discover the distribution of antibiotic-resistance genes on Staphylococcal subclinicalmastitis agents in several regencies of East Java.

\section{Sampling of Subclinical Mastitis Milk}

Subclinical-mastitis milk-samples were obtained by purposive sampling method with size $10 \%$ from a population (with criteria: all cow on lactating phase) in Regencies of Jember, Malang, Lumajang, Probolinggo, Mojokerto, Pasuruan, Banyuwangi, and Sidoarjo based on high dairy cattle populations in several regencies of East Java (Ministry of Agriculture, 2020). For each regen$\mathrm{cy}$, the farms with the largest cattle population through stratified random sampling were chosen according to Windria et al. (2016). Samples of subclinical mastitis were selected by California mastitis test (CMT) analysis. A total of $10 \mathrm{~mL}$ milk per quarter of all individual lactating cows from 62 selected farms were collected on the tube and were identified by CMT reaction. The shape of the viscous mass on the CMT reaction was marked as a positive reaction with the reaction grade of $-,+1,+2,+3$ (Harjanti \& Sambodo, 2020). The positive CMT samples were then processed for phenotypic identification of $S$. epidermidis and genotypic identification of $S$. aureus and NAS species.

\section{Isolation and Identification of Staphylococcal Isolates}

All subclinical mastitis samples were grown on Nutrient Agar plate (NA, CM0003B, Oxoid, England) following sub-culturing on Staphylococcus selective media such as Mannitol Salt Agar (MSA, CM0085W, Oxoid, England) and Staphylococcus Agar 110 (SA 110, M521, HiMedia, India). Each medium was incubated at $37^{\circ} \mathrm{C}$ for 24 hours (Carter \& Wise, 2004) for phenotypic determination. The colony representing Staphylococcus species was characterized by observing the colonies of microbial-based on the specifications in the Certificate of Analysis of Quality Control Laboratory Oxoid Limited, Basingstoke (2020) and HiMedia Laboratories Pvt, India. A colony with pink color on the MSA media was identified as S. epidermidis, whereas a colony with a color changed from pink to yellow was identified as S. aureus. In addition, the colony of $S$. aureus produced pigment on SA 110 media but not S. epidermidis.

Additionally, a molecular-based determination for particular S. aureus isolates was done using polymerase chain reaction (PCR) technique (Widianingrum et al., 2016). Briefly, the DNA of staphylococci isolates was isolated following Windria et al. (2016) and subjected to a 35 standard cycle PCR condition with a specific annealing temperature (Table 1). All isolates with no specific $23 S$ rRNA gene were then grouped into NAS species.

\section{Determination of Antibiotic-Resistant Genes in Staphylococcal Isolates}

The presence of antibiotic-resistant genes in bacterial isolates (S. aureus, S. epidermidis, and NAS species) was detected through standard PCR techniques using specific pair-primers (Table 1). The specific DNA sequence responsible for particular antibiotic-resistant genes in Staphylococcus species was amplified in standard PCR conditions. The condition was described previously by Widianingrum et al. (2016) with a temperature of pre-denaturation at $94{ }^{\circ} \mathrm{C}$ for 120 seconds, followed by 30 cycles of denaturation at $94{ }^{\circ} \mathrm{C}$ for 30 seconds, annealing (the temperature depends on pairprimers) for 30 seconds, and extension at $72{ }^{\circ} \mathrm{C}$ for 60 seconds before a post-extension at $72{ }^{\circ} \mathrm{C}$ for 200 seconds. The amplicon was analyzed based on the size of the am-

Table 1. Oligonucleotide primers coding Staphylococcus aureus and antibiotic-resistant genes

\begin{tabular}{|c|c|c|c|c|}
\hline Gene & Primer sequence & Annealing $\left({ }^{\circ} \mathrm{C}\right)$ & Target Size (bp) & Reference \\
\hline \multirow[t]{2}{*}{$23 \mathrm{~S}$ rRNA } & 5’ AGCGAGTTACAAAGGAGGAC 3' & 64 & 1250 & Straub et al., 1999 \\
\hline & 3’ AGCTCAGCCTTAACGAGTAC 5' & & & \\
\hline \multirow[t]{2}{*}{ MecA } & 5’ AAAATCGATGGTAAAGGTTGGC 3' & 55 & 532 & Strommenger et al., 2003 \\
\hline & 3’ AGTTCTGCAGTACCGGATTTGC 5' & & & \\
\hline \multirow[t]{2}{*}{ blaZ } & 5’ ACTTCAACACCTGCTGCTTTC 3’ & 61 & 173 & Martineau et al., 2000 \\
\hline & 3' TGACCACTTTTATCA GCAACC 5' & & & \\
\hline \multirow[t]{2}{*}{ tetK } & 5' GTAGCGACAATAGGTAATAGT 3' & 55 & 360 & Strommenger et al., 2003 \\
\hline & 3' GTAGTGACAATAAACCTCCTA 5' & & & \\
\hline \multirow[t]{2}{*}{ tetM } & 5’ AGTGGAGCGATTACAGAA 3’ & 55 & 158 & Strommenger et al., 2003 \\
\hline & 3’ CATATGTCCTGGCGTGTCTA 5' & & & \\
\hline
\end{tabular}


plicon in $1 \%$ agarose visualized with UV transilluminator (Sakura). A 100 bp DNA ladder (Vivantis) was used as a molecular ruler (Widianingrum et al., 2016).

\section{Data Analysis}

The percentage of incidence of subclinical mastitis and Staphylococcal subclinical mastitis were analyzed descriptively. The species were grouped according to the California Mastitis Test (CMT) then its relationship was analyzed through bivariate Pearson Correlation by a two-tailed significance test using SPSS version 21.0.

\section{RESULTS}

In this study, 397 out of 592 samples (67\%) were identified as subclinical mastitis found in several regencies of East Java, Indonesia. This incidence of subclinical mastitis was in the range with the highest percentage of CMT +1 presented at $42 \%$, while the lowest CMT +2 was at $21 \%$ (Table 2 ). In addition, the data showed that about $51 \%$ of subclinical mastitis incidents were caused by Staphylococcus species determined as NAS, S. epidermidis, and S. aureus at the portion of $47 \%, 14 \%$, and $5 \%$, respectively (Figure 1).

According to the data, Staphylococcal subclinical mastitis was distributed at eight regions in several regencies of East Java. The Region of Jember was the most prevalent area with all types of Staphylococcus species found in the area. The distribution of $S$. aureus was uncertainly present in mastitis, with a CMT score of +3 found in the Malang region. In addition, similar S. aureus was also found in Jember and Probolinggo regions but presented at lower CMT scores (Table 3). However, relationship analysis reveals a low correlation between CMT and the identification result of Staphylococcus species with a positive value of the correlation only

Table 2. Incidence of subclinical mastitis in several regencies of East Java, Indonesia

\begin{tabular}{|c|c|c|c|c|}
\hline \multirow{2}{*}{$\begin{array}{l}\text { Total of } \\
\text { samples }\end{array}$} & \multirow{2}{*}{$\begin{array}{l}\text { Subclinical } \\
\text { mastitis }\end{array}$} & \multicolumn{3}{|c|}{$\begin{array}{l}\text { Number of samples on California } \\
\text { Mastitis Test (CMT) }\end{array}$} \\
\hline & & $\mathrm{CMT}+1$ & $\mathrm{CMT}+2$ & $\mathrm{CMT}+3$ \\
\hline 592 & 397 (67\%) & $169(42 \%)$ & $82(21 \%)$ & $146(37 \%)$ \\
\hline \multicolumn{5}{|c|}{$\begin{array}{l}\text { Note: } \mathrm{CMT}+1=\text { low reaction, } \mathrm{CMT}+2=\text { medium reaction, } \mathrm{CMT}+3=\text { high } \\
\text { reaction }\end{array}$} \\
\hline $\begin{array}{l}\text { Other agents } \\
\quad 34 \%\end{array}$ & & & & $\begin{array}{c}\text { Non-aureus } \\
\text { Staphylococci; } \\
47 \%\end{array}$ \\
\hline $\begin{array}{l}\text { Staphylococe } \\
\text { aureus; } 5 \%\end{array}$ & & & & \\
\hline
\end{tabular}

Figure 1. Presence of Staphylococcal subclinical mastitis in several regencies of East Java. (NAS $=49$ isolates, Staphylococcus aureus $=5$ isolates, Staphylococcus epidermidis $=14$ isolates, other agents $=35$ samples $)$. between CMT and NAS species (Table 4). This result indicates that the Staphylococcus species did not always associate with the level of CMT result in several regions in several regencies of East Java (Figure 1, Table 3).

Interestingly, the data showed that only five samples positively carried an antibiotic-resistant blaZ gene found in the species isolated from farms in Mojokerto, Malang, Probolinggo, and Banyuwangi regions. All samples belonged to non-aureus Staphylococci (NAS) species. However, no mecA, tet $K$, and tet $M$ antibioticresistant genes were found in all isolates (Table 5, Figure 2).

\section{DISCUSSION}

Farmers and researchers often ignore the incidence of mastitis with a CMT +1 score. This situation also oc-

Table 3. Distribution of Staphylococcus sp. causing subclinical mastitis in several regencies of East Java

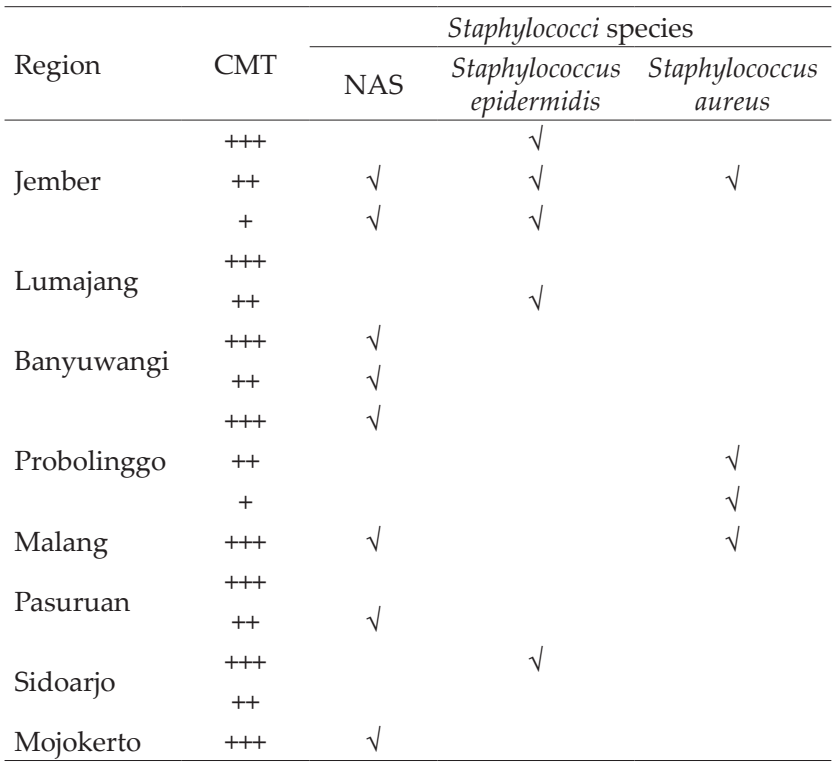

Note: NAS= non-aureus Staphylococci; $\mathrm{CMT}=$ California Mastitis Test.

Table 4. Coefficient correlation of Bivariate Pearson (r)

\begin{tabular}{lccc}
\hline \multirow{2}{*}{ Variable } & \multicolumn{3}{c}{ Staphylococci species } \\
\cline { 2 - 4 } & NAS & $\begin{array}{c}\text { Staphylococcus } \\
\text { epidermidis }\end{array}$ & $\begin{array}{c}\text { Staphylococcus } \\
\text { aureus }\end{array}$ \\
\hline CMT & 0.129 & -0.12 & -0.301 \\
Sig (2-tailed) & 0.128 & 0.159 & 0 \\
\hline
\end{tabular}

Note: NAS= non-aureus Staphylococci

Table 5. Detection of antibiotic-resistant genes in Staphylococcus $\mathrm{sp}$. isolates

\begin{tabular}{lccc}
\hline \multirow{2}{*}{$\begin{array}{c}\text { Antibiotic-resistant } \\
\text { related genes }\end{array}$} & \multicolumn{3}{c}{ Number of Staphylococci species } \\
\cline { 2 - 4 } mecA $A$ & NAS & $\begin{array}{c}\text { Staphylococcus } \\
\text { epidermidis }\end{array}$ & $\begin{array}{c}\text { Staphylococcus } \\
\text { aureus }\end{array}$ \\
blaZ & 0 & 0 & 0 \\
tetK & 5 & 0 & 0 \\
tet $M$ & 0 & 0 & 0 \\
\hline
\end{tabular}

Note: NAS= non-aureus Staphylococci 


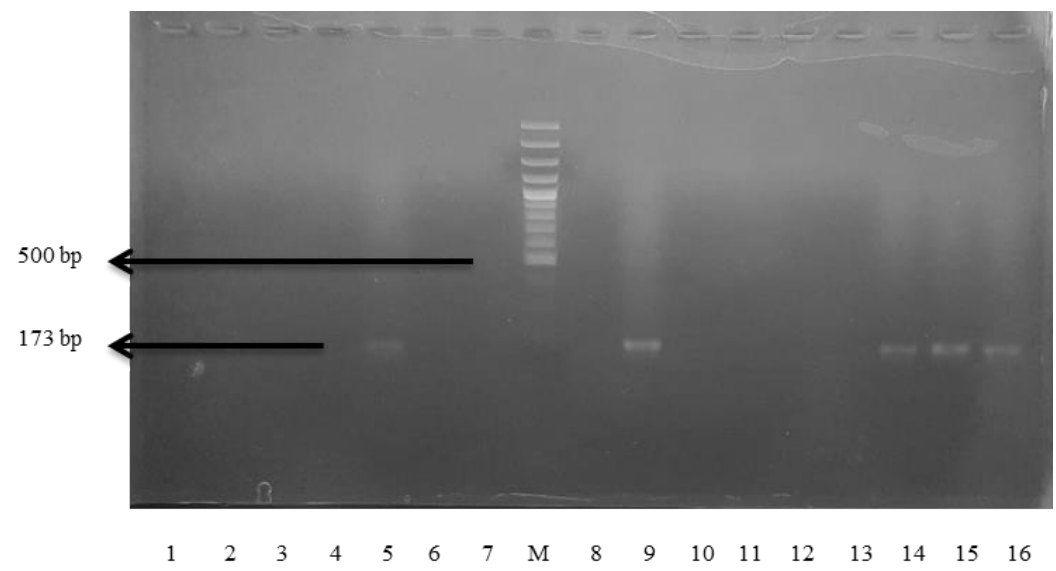

Figure 2. PCR electrophoresis results on antibiotic-resistant genes. (Line 1,2,3= $m e c A$ negative; $4,6=$ bla $Z$ negative; $5,9=$ blaZ positive; $7,8=$ tet $K$ negative; $M=100$ bp molecular-size DNA ladder; $10,11,12,13=$ tet $M$ negative; $14,15,16=$ blaZ positive).

curs throughout all regions of Indonesia and over the world. Cheng et al. (2021) only examined mastitis cases with scores ranging from CMT +2, Leitner et al. (2018) only from $\mathrm{CMT}+3$. In our findings, it was known that at $\mathrm{CMT}+1$ there was a higher bacterial variation in CMT +1 results. In other studies, Mekonnen et al. (2017) found 10 types with a total of 139 bacteria on CMT +1 compared to negative CMT results (5 types with a total of 86 bacteria), CMT +2 (8 types with a total of 116 bacteria), and CMT +3 ( 8 types with a total of 60 bacteria). Similar findings were also reported by Akter et al. (2020). This fact provides information that farmers should start giving medication to their livestock if the mastitis incident occurs at a $\mathrm{CMT}+1$.

Identification of bacteria using MSA selective media is commonly used to determine among Staphylococci species (Ramandinianto et al., 2020; Arjyal et al., 2020). In MSA media, the $S$. epidermidis grow as a pink-color colony. In contrast, $S$. aureus grows as a yellow-color colony surrounded by a yellow halo on the pink-colored MSA medium (Subramanian et al., 2017). In addition, a Staphylococcus Agar 110 media was used to select particular species that belonged to $S$. aureus because of pigment formation during the bacteria growth. The detection for $23 S$ rRNA sequence using specific primers (Table 1) in all isolates reveals that not all Staphylococci isolates belong to $S$. aureus (Figure 1). This result suggested that a combination approach to determine, identify, and distinguish Staphylococcus species can be done using Staphylococci selective media and detection of $23 S$ rRNA sequence simultaneously. This approach has been used to detect the high sensitivity and unambiguity contaminants in food and distinguish S. aureus from other related bacteria (Straub et al., 1999). In addition to the approach, the Staphylococci species with no specific $23 S$ rRNA sequence are grouped into NAS species instead of S. epidemidis. Windria et al. (2016) reported that the species with similar phenotypic features growth in Staphylococci selective media are S. aureus, S. pasteuri, S. haemoliticus, and S. xylosus.

The correlation between CMT and species of Staphylococci can be used as early warning support of subclinical mastitis incidents. The low correlation in this study (Table 4) indicates the dangerous pathogen S. aureus associated with mastitis is present and should start to be considered, although in the lower score of CMT $(\mathrm{CMT}+1)$. S. aureus is an agent that needs to be considered because of its pathogenicity and is highly contagious (Song et al., 2020). More than 40 virulent $S$. aureus were reported (Yang et al., 2015). In addition, S. aureus has pathogenicity factors incorporated into its ability in producing enterotoxins (Mama et al., 2021; Cretenet et al., 2011; Aziz et al., 2020), forming a biofilm (Raza et al., 2013), and encoding two conserved proteins glyceraldehyde-3-phosphate dehydrogenase-B (GapB) and -C (GapC) (Kerro-Dego et al., 2012).

CMT was used for subclinical mastitis detection because it is effective, cheap, and easy to apply in the field. The basic CMT reaction has been described by Bachaya et al. (2011) that CMT causes leakage of somatic cells on milk resulting in the release of DNA. The released DNA (acid) is then reacted with alkyl-arylsulfonate (alkaline) to form a gel, where the gel consistency depends on the total somatic cell count (SCC). The results of the CMT reaction are of greater value (from negative, $+1,+2$, +3 ) with increasing SCC in milk (Harjanti \& Sambodo, 2020). However, the amount of SCC produced does not depend on the number of bacteria instead of bacterial species that induce SCC. For example, Bacillus spp induces the highest SCC at the population of 713.67 $\times 10^{3}$ cells $/ \mathrm{mL}$ compared to $S$. aureus at the population of $373.82 \times 10^{3}$ cells $/ \mathrm{mL}$ and coagulase-negative Staphylococcus (CNS) at the population of $182.67 \times 10^{3}$ cells/mL (Sumon et al., 2017).

S. aureus was found in only $5 \%$ in this study. The low percentage of this species cannot be ignored because $S$. aureus was reported to cause chronic infections (Mohandes et al., 2021) and is potentially resistant to various antibiotics (Widianingrum et al., 2016).

This study found several NAS species carry the blaZ gene (Table 5), suggesting that penicillin-resistant NAS species exist in mastitis in several regencies of East Java. The discovery of the blaZ gene in NAS species in East Java can be an illustration of the situation that may 
occur in Indonesia, as we know the lack of research data on NAS. NAS species are often underestimated as the cause of mastitis. Researchers in almost all of Indonesia focus more on the type of $S$. aureus (Widianingrum et al., 2016; Salasia et al., 2011; Lucia et al., 2017).

NAS becomes a concern because they have 40 to $50 \%$ virulence genes of S. aureus (Åvall-Jääskeläinen, 2018). A study by Mahmmod et al. (2018) shows that $76 \%$ of NAS can cause infection in the mammary glands (S. epidermidis, S. haemolyticus, S. chromogenes) and $73 \%$ of NAS species infecting teat skin (S. equorum, $S$. haemolyticus, S. cohnii). Despite the penicillin-resistant NAS species exist in few numbers, the NAS species carrying the blaZ gene should be considered to address the other alternative treatments for Staphylococcal subclinical mastitis. Moreover, according to the interview during sampling, the information reveals that most farmers did not know the type of antibiotic used, but some farmers mentioned that they used Penicillin to treat sick cattle. The emergence of resistant strains makes bacterial infections more difficult to treat (Zaman et al., 2017).

Previously, the use of other types of antibiotics has been recommended to treat Staphylococcal subclinical mastitis (Tahmasedi et al., 2017). However, this recommendation is no longer suitable because $87.5 \%$ of MRSA strains developed by carrying the blaZ gene. These facts suggest that alternative treatments are needed to combat Staphylococcal subclinical mastitis in dairy farms (Widianingrum et al., 2016; Widianingrum et al., 2019). Resistance mechanisms were summarized by Handayani et al. (2017), including inappropriate use, wrong knowledge of the user, the use of monotherapy, easy to get and the massive sales by pharmaceutical companies, also antibiotics use for animals and livestock.

The implication from our finding is milk produced will transmit antibiotic-resistant microbes to humans who consume the milk so that the impact can be on the prevalence of antibiotic-resistant microbes in humans. Widianingrum et al. (2016) observed the resistance that occurred in samples of livestock (goat and cow's milk) and humans (vomit and skin infections) due to $S$. aureus, it was found that $80 \%$ of isolates in humans, $76.92 \%$ in bovine, and $41.67 \%$ in goat have been resistant to ampicillin (ampicillin is one of the penicillin antibiotics group). Resistance to ampicillin and penicillin in clinical and subclinical mastitis cases was investigated by Saini et al. (2012). Their study reported that $35.4 \%$ of $S$. aureus in herds were resistant to penicillin and half to ampicillin.

In the study of dairy products, Spanu et al. (2012) investigated the pattern of resistance genes from $S$. aureus isolated from cheese. It was known that from 20 kinds of cheese from 10 sheep cheese dairy companies in Sardinia (Italy), 19 isolates have the blaZ gene, 5 isolates have the Tet $L$ gene, 21 isolates have the Tet $M$ gene, 1 isolate has the TetS and TetW genes. Biovar analysis (probable origin of contamination) was also investigated in their study. It was known that $81 \%$ came from "animal" biovars and $16 \%$ from "human" biovar.

The pattern of virulence genes and the data of genetic polymorphism can be used to determine the relationship origin of the isolates. All the statements that have been described illustrate a resistance relationship between animals, the environment, and bacteria in processed products and in humans. So, we summarize several strategies for prevention and treatment measures, including 1. Early diagnostics to determine strategies earlier (Griffioen et al., 2021) 2. Antibiotic residues in milk selectively support bacterial antibiotic resistance (Brown et al., 2020), so the use of antibiotics in treating mastitis cases must be selective, careful, and wise. 3 . The use of natural ingredients containing immunomodulators and antibacterial that do not cause antimicrobial resistance, such as virgin coconut oil (Widianingrum et al., 2019), binahong (Widodo et al., 2020), or probiotics (Barker et al., 2020). 4. Milking management improvements such as using milking machines and supplementation with vitamin E and selenium (Ruegg, 2017). 5. Using modern technology such as genetic engineering and biotechnology (Cardoso et al., 2019), genomic selection (Kaniyamattam et al., 2020), and nanoemulsion formula (Machado et al., 2020), etc.

\section{CONCLUSION}

This study concludes that a blaZ gene (encoding to penicillin resistance) in NAS bacteria causes subclinical mastitis in Mojokerto, Malang, Probolinggo, and Banyuwangi. This finding indicates that this species needs to be considered besides $S$. aureus and S. epidermidis. NAS becomes concerned because it can cause infection of the mammary glands and teat skin, increasing the incidence of mastitis. Alternative mastitis treatments are needed to avoid future risks.

\section{CONFLICT OF INTEREST}

We certify that there is no conflict of interest with any financial, personal, or other relationships with other people or organizations related to the material discussed in the manuscript.

\section{ACKNOWLEDGEMENT}

This research was financially supported by LP2M University of Jember with the grant Number of 3455/ UN25.3.1/LT/2020. We are thankful to the farmers in several regencies of East Java, Indonesia, for their cooperation on our project.

\section{REFERENCES}

Abebe, R., H. Hatiya, M. Abera, B. Megersa, \& K. Asmare. 2016. Bovine mastitis: Prevalence, risk factors and isolation of Staphylococcus aureus in dairy herds at Hawassa milk shed, South Ethiopia. BMC Vet. Res. 12:1-11. https:// doi.org/10.1186/s12917-016-0905-3

Akter, S., M. M. Rahman, M. A. Sayeed, M. N. Islam, D. Hossain, M. A. Hoque, \& G. Koop. 2020. Prevalence, aetiology and risk factors of subclinical mastitis in goats in Bangladesh. Small Rumin. Res. 184:106046. https://doi. org/10.1016/j.smallrumres.2020.106046

Arjyal, C., K. C. Jyoti, \& N. Neupane. 2020. Prevalence of methicillin-resistant Staphylococcus aureus in 
Shrines. Int. J. Microbiol. 2020:7981648. https://doi. org $/ 10.1155 / 2020 / 7981648$

Aslam, B., W. Wang, M. I. Arshad, M. Khurshid, S. Muzammil, M. H. Rasool, M. A. Nisar, R. F. Alvi, M. A. Aslam, M. U. Qamar, M. Salamat, \& Z. Baloch. 2018. Antibiotic resistance: A rundown of a global crisis. Infect. Drug Resist. 11:1645-1658. https://doi.org/10.2147/IDR.S173867

Åvall-Jääskeläinen, S., S. Taponen, R. Kant, L. Paulin, J. Blom, A. Palva, \& J. Koort. 2018. Comparative genome analysis of 24 bovine-associated Staphylococcus isolates with special focus on the putative virulence genes. PeerJ 6:e4560. https://doi.org/10.7717/peerj.4560

Aziz, F., J. Hisatsune, L. Yu, J. Kajimura, Y. Sato'o, H. K. Ono, K. Masuda, M. Yamaoka, S. I. O. Salasia, A. Nakane, \& H. Ohge. 2020. Staphylococcus aureus isolated from skin from atopic-dermatitis patients produces Staphylococcal enterotoxin $\mathrm{Y}$, which predominantly induces T-cell receptor $\mathrm{V} \alpha$-specific expansion of T cells. Infect. Immun. 88:e036019 https://doi.org/10.1128/IAI.00360-19

Bachaya, H. A., M. A. Raza, S. Murtaza, \& I. U. R. Akbar. 2011. Subclinical bovine mastitis in Muzaffar Garh district of Punjab (Pakistan). J. Anim. Plant Sci. 21:16-19.

Barker, M., P. Adelson, M. D. Peters, \& M. Steen. 2020. Probiotics and human lactational mastitis: A scoping review. Women Birth 13:e483-e491. https://doi.org/10.1016/j. wombi.2020.01.001

Brown, K., M. Mugoh, D. R. Call, \& S. Omulo. 2020. Antibiotic residues and antibiotic-resistant bacteria detected in milk marketed for human consumption in Kibera, Nairobi. PLoS ONE 15:e0233413. https://doi.org/10.1371/journal. pone. 0233413

Cardoso, C. V., E. V. Barbosa, M. H. T. Liberal, \& E. F. das Chagas. 2019. Transgenic technology: the strategy for the control and prevention of bovine staphylococcal mastitis? Biotechnol. Res. Innov. 3:291-297. https://doi.org/10.1016/j. biori.2019.08.001

Carter, G. R. \& D. J. Wise. 2004. Essentials of veterinary bacteriology and mycology. $6^{\text {th }}$ Ed. Iowa State Press. A Blackwell Publishing Company, Iowa.

Cervinkova D., H. Vlkova, I. Borodacova, J. Makovcova, V. Babak, A. Lorencova, I. Vrtkova, D. Marosevic, \& Z. Jaglic. 2013. Prevalence of mastitis pathogens in milk from clinically healthy cows. Vet. Med. 58:567-575. https://doi. org/10.17221/7138-VETMED

Chandrasekaran, D., P. Venkatesan, K. G. Tirumurugaan, A. P. Nambi, P. S. Thirunavukkarasu, K. Kumanan, S. Vairamuthu, \& S. Ramesh. 2014. Pattern of antibiotic resistant mastitis in dairy cows. Vet. World. 7:389-394. https://doi.org/10.14202/vetworld.2014.389-394

Cheng, J., M. Zhou, D. B. Nobrega, Z. Cao, J. Yang, C. Zhu. \& J. Gao. 2021. Virulence profiles of Klebsiella pneumoniae isolated from 2 large dairy farms in China. Int. J. Dairy Sci. 104:9027-9036. https://doi.org/10.3168/jds.2020-20042

Cretenet, M., S. Even, \& Y. Le Loir. 2011. Unveiling Staphylococcus aureus enterotoxin production in dairy products: a review of recent advances to face new challenges. Dairy Sci. Technol. 91:127-150. https://doi.org/10.1007/ s13594-011-0014-9

Gonçalves, J. L., C. Kamphuis, H. Vernooij, J. P. Araújo Jr, R. C. Grenfell, L. Juliano, K. L. Anderson, H. Hogeveen, \& M. V. Dos Santos. 2020. Pathogen effects on milk yield and composition in chronic subclinical mastitis in dairy cows. Vet. J. 262:105473. https://doi.org/10.1016/j.tvj1.2020.105473

Griffioen, K., A. G. Velthuis, G. Koop, \& T. J. Lam. 2021. Effects of a mastitis treatment strategy with or without on-farm testing. Int. J. Dairy Sci. 104:4665-4681. https://doi. org/10.3168/jds.2019-17871

Handayani, R. S., S. Siahaan, \& M. J. Herman. 2017. Antimicrobial resistance and its control policy implementation in hospital in Indonesia. Jurnal Penelitian dan Pengembangan Pelayanan Kesehatan 1:131-140. https://doi.org/10.22435/jpppk.v1i2.537

Harjanti, D. W. \& P. Sambodho. 2020. Effects of mastitis on milk production and composition in dairy cows. Earth Environ. Sci. 518:012032. https://doi. org/10.1088/1755-1315/518/1/012032

Heikkilä, A. M., E. Liski, S. Pyörälä, \& S. Taponen. 2018. Pathogen-specific production losses in bovine mastitis. J. Dairy Sci. 101:9493-9504. https://doi.org/10.3168/ jds.2018-14824

Hoekstra, J., Zomer, A. L., Rutten, V. P. M. G. 2020. Genomic analysis of European bovine Staphylococcus aureus from clinical versus subclinical mastitis. Sci. Rep. 10:18172. https://doi.org/10.1038/s41598-020-75179-2

Kaniyamattam, K., A. De Vries, L. W. Tauer, \& Y. T. Gröhn. 2020. Economics of reducing antibiotic usage for clinical mastitis and metritis through genomic selection. J. Dairy Sci. 103:473-491. https://doi.org/10.3168/jds.2018-15817

Kerro-Dego, O., T. Prysliak, J. Perez-Casal, \& A. A. Potter. 2012. Role of GapC in the pathogenesis of Staphylococcus aureus. Vet. Microbiol. 156:443-447. https://doi.org/10.1016/j. vetmic.2011.11.018

Khairullah, A. R., D. Raharjo, J. Rahmahani, Suwarno, W. Tyasningsih, \& N. Harijani. 2019. Antibiotics resistant at Staphylococcus aureus and Streptococcus sp isolated from bovine mastitis in Karangploso, East Java, Indonesia. Indian J. Forensic Med. Toxicol. 13:451-456. https://doi. org/10.5958/0973-9130.2019.00329.3

Koop, G., T. Van Werven, H. J. Schuiling, \& M. Nielen. 2010. The effect of subclinical mastitis on milk yield in dairy goats. J. Dairy Sci. 93:5809-5817. https://doi.org/10.3168/ jds.2010-3544

Leitner, G., D. Zilberman, E. Papirov, \& S. Shefy. 2018. Assessment of acoustic pulse therapy (APT), a non-antibiotic treatment for dairy cows with clinical and subclinical mastitis. PLoS ONE 13:e0199195. https://doi.org/10.1371/ journal.pone.0199195

Lucia, M., S. Rahayu, D. Haerah, \& D. Wahyuni. 2017. Detection of Staphylococcus aureus and Streptococcus agalactiae: Subclinical mastitis causes in dairy cow and dairy buffalo (Bubalus Bubalis). Am. J. Biomed. Res. 5:8-13.

Machado, G. T. P., M. B. Veleirinho, L. A. Honorato, \& S. Kuhnen. 2020. Formulation and evaluation of anti-MRSA nanoemulsion loaded with Achyrocline satureioides: A new sustainable strategy for the bovine mastitis. Nano Express 1:030004. https://doi.org/10.1088/2632-959X/ abbcac

Mahmmod, Y. S., I. C. Klaas, L. Svennesen, K. Pedersen, \& H. Ingmer. 2018. Communications of Staphylococcus aureus and non-aureus Staphylococcus species from bovine intramammary infections and teat apex colonization. J. Dairy Sci. 101:7322-7333. https://doi.org/10.3168/jds.2017-14311

Mama, O. M., L. Morales, L. Ruiz-Ripa, M. Zarazaga, \& C. Torres. 2020. High prevalence of multidrug resistant S. aureus-CC398 and frequent detection of enterotoxin genes among non-CC398 S. aureus from pig-derived food in Spain. Int. J. Food Microbiol. 320:108510. https://doi. org/10.1016/j.ijfoodmicro.2020.108510

Martineau, F., F. J. Picard, N. Lansac, C. Ménard, P. H. Roy, M. Ouellette, \& M. G. Bergeron. 2000. Correlation between the resistance genotype determined by multiplex PCR assays and the antibiotic susceptibility patterns of Staphylococcus aureus and Staphylococcus epidermidis. Antimicrob. Agents Chemother. 44:231-238. https://doi. org/10.1128/AAC.44.2.231-238.2000

Mbindyo, C. M., G. C. Gitao, \& C. M. Mulei. 2020. Prevalence, etiology, and risk factors of mastitis in dairy cattle in Embu 
and Kajiado Counties, Kenya. Vet. Med. Int. 2020:8831172. https://doi.org/10.1155/2020/8831172

Mekonnen, S. A., G. Koop, S. T. Melkie, C. D. Getahun, H. Hogeveen, \& T. J. Lam. 2017. Prevalence of subclinical mastitis and associated risk factors at cow and herd level in dairy farms in North-West Ethiopia. Prev. Vet. Med. 145:23-31. https://doi.org/10.1016/j.prevetmed.2017.06.009

Ministry of Agriculture. 2020. Livestock and Animal Health Statistics 2020. Directorate General Livestock and Animal Health Ministry of Agriculture Republic Indonesia. Jakarta, Indonesia.

Mohandes, S. S. E., I. M. Gamal, H. A. Abou-Zeina, \& M. K. Elbayoumy. 2021. Some studies on phenotypic and genotypic characters of small colony variants Staphylococcus aureus isolated from dairy cows infected with mastitis in Egypt. Adv. Anim. Vet. Sci. 9:637-647. https://doi. org/10.17582/journal.aavs/2021/9.5.637.647

Oliveira, L., C. Hulland, \& P. L. Ruegg. 2013. Characterization of clinical mastitis occurring in cows on 50 large dairy herds in Wisconsin. J. Dairy Sci. 96:7538-7549. https://doi. org $/ 10.3168 / j d s .2012-6078$

Poizat, A., F. Bonnet-Beaugrand, A. Rault, C. Fourichon, \& N. Bareille. 2017. Antibiotic use by farmers to control mastitis as influenced by health advice and dairy farming systems. Prev. Vet. Med. 146:61-72. https://doi.org/10.1016/j. prevetmed.2017.07.016

Ramandinianto, S. C., A. R. Khairullah, \& M. H. Effendi. 2020. MecA gene and methicillin-resistant Staphylococcus aureus (MRSA) isolated from dairy farms in East Java, Indonesia. Biodiversitas 218:3562-3568. https://doi.org/10.13057/ biodiv/d210819

Raza, A., G. Muhammad, S. Sharif, \& A. Atta. 2013. Biofilm producing Staphylococcus aureus and bovine mastitis: a review. Mol. Microbiol. Res. 3:1-8. https://doi.org/10.5376/ mmr.2013.03.0001

Ruegg, P. L. 2017. A 100-Year Review: Mastitis detection, management, and prevention. J. Dairy Sci. 100:10381-10397. https://doi.org/10.3168/jds.2017-13023

Saini, V., J. T. McClure, D. T. Scholl, T. J. DeVries, \& H. W. Barkema. 2012. Herd-level association between antimicrobial use and antimicrobial resistance in bovine mastitis Staphylococcus aureus isolates on Canadian dairy farms. J. Dairy Sci. 95:1921-1929. https://doi.org/10.3168/ jds.2011-5065

Salasia, S. I. O., S. Tato, N. Sugiyono, D. Ariyanti, \& F. Prabawati. 2011. Genotypic characterization of Staphylococcus aureus isolated from bovines, humans, and food in Indonesia. J. Vet Sci. 12:353-361. https://doi. org/10.4142/jvs.2011.12.4.353

Song, X., X. Huang, H. Xu, C. Zhang, S. Chen, F. Liu, S. Guan, S. Zhang, K. Zhu, \& C. Wu. 2020. The prevalence of pathogens causing bovine mastitis and their associated risk factors in 15 large dairy farms in China: An observational study. Vet. Microbiol. 247:108757. https://doi.org/10.1016/j. vetmic.2020.108757

Spanu, V., C. Spanu, S. Virdis, F. Cossu, C. Scarano, \& E. P. L. De Santis. 2012. Virulence factors and genetic variability of Staphylococcus aureus strains isolated from raw sheep's milk cheese. Int. J. Food Microbiol. 153:53-57. https://doi. org/10.1016/j.ijfoodmicro.2011.10.015
Straub, J. A., C. Hertel, \& W. P. Hammes. 1999. A 23 S rDNAtargeted polymerase chain reaction based system for detection of Staphylococcus aureus in meat starter cultures and dairy products. J. Food Prot. 62:1150-115. https://doi. org/10.4315/0362-028X-62.10.1150

Strommenger, B., C. Kettlitz, G. Werner, \& W. Witte. 2003. Multiplex PCR assay for simultaneous detection of nine clinically relevant antibiotic resistance genes in Staphylococcus aureus. J. Clin. Microbiol. 41:4089-4094. https://doi.org/10.1128/JCM.41.9.4089-4094.2003

Subramanian, A., V. K. Chitalia, K. Bangera, S. P. Vaidya, R. Warke,A.Chowdhary \& R.A.Deshmukh. 2017. Evaluation of HiaureusTM coagulase confirmation kit in identification of Staphylococcus aureus. J. Clin. Diag. Res. 11:DC08DC13. https://doi.org/10.7860/JCDR/2017/24021.9265

Sumon, S. M. M. R., M. A. Ehsan, \& M. T. Islam. 2017. Subclinical mastitis in dairy cows: Somatic cell counts and associated bacteria in Mymensingh, Bangladesh. J. Bangladesh Agril. Univ. 15:266-271. https://doi.org/10.3329/jbau.v15i2.35073

Tahmasebi, H., B. Zeyni, S. Dehbashi, H. Motamedi, M. Vafaeefar, F. Keramat, \& M. R. Arabestani. 2017. The study of blaZ and mecA gene expression in methicillinresistant Staphylococcus aureus strains and the relationship between the gene expression patterns. J. Isfahan Medical School. 35:1062-1067.

Vishnuraj, M. R., G. Kandeepan, K. H. Rao, S. Chand, \& V. Kumbhar. 2016. Occurrence, public health hazards and detection methods of antibiotic residues in foods of animal origin: A comprehensive review. Cogent Food Agric. 2:1235458. https://doi.org/10.1080/23311932.2016.1235458

Widianingrum D. C., C. T. Noviandi, \& S. I. O. Salasia. 2019. Antibacterial and immunomodulatory activities of Virgin Coconut Oil (VCO) against Staphylococcus aureus. Heliyon 5:1-5. https://doi.org/10.1016/j.heliyon.2019.e02612

Widianingrum D. C., S. Windria, \& S. I. O. Salasia. 2016. Antibiotic resistance and methicillin resistant Staphylococcus aureus isolated from bovine, crossbred Etawa goat and human. Asian J. Anim. Vet. Adv. 11:122129. https://doi.org/10.3923/ajava.2016.122.129

Windria, S., D. C. Widianingrum, \& S. I. O. Salasia. 2016. Identification of Staphylococcus aureus and coagulase negative Staphylococci isolates from mastitis milk of Etawa crossbred goat. Res. J. Microbiol. 11:11-19. https://doi. org/10.3923/jm.2016.11.19

Yang, F., Q. Wang, X. Wang, L. Wang, M. Xiao, X. Li, J. Luo, S. Zhang, \& H. Li. 2015. Prevalence of blaZ gene and other virulence genes in penicillin-resistant Staphylococcus aureus isolated from bovine mastitis cases in Gansu, China. Turkish J. Vet. Animal Sci. 39:634-636. https://doi. org/10.3906/vet-1504-81

Yuan, Y. G., Q. L. Peng, \& S. Gurunathan. 2017. Effects of silver nanoparticles on multiple drug-resistant strains of Staphylococcus aureus and Pseudomonas aeruginosa from mastitis-infected goats: an alternative approach for antimicrobial therapy. Int. J. Mol. Sci. 18:569. https://doi. org/10.3390/ijms18030569

Zaman, S. B., M. A. Hussain, R. Nye, V. Mehta, K. T. Mamun, \& N. Hossain. 2017. A review on antibiotic resistance: Alarm bells are ringing. Cureus 9:e1403. https://doi.org/10.7759/ cureus.1403 